\title{
Note
}

\section{Advancement of oral squamous cell carcinoma due to careless tooth extraction : Two canine cases}

\author{
Takeshi Ishikawa $^{1)}$, Takuo Shida ${ }^{1,2)}$, Takuya Maruo ${ }^{1)}$, Hiroki Sugiyama ${ }^{1)}$, \\ Kayo Kanakubo ${ }^{3)}$, Tetsuro Ito ${ }^{1)}$, Hideki Kayanuma ${ }^{1,2)}$ and Tsunenori Suganuma ${ }^{1,2)}$
}

\begin{abstract}
Two dogs with gingival lesions were treated with simultaneous tooth extraction and lesion removal. The lesions were diagnosed as squamous cell carcinoma, and due to early recurrence, the dogs were brought to the Azabu University Veterinary Teaching Hospital. Computer tomography (CT) findings confirmed nasal cavity invasion in both cases. In Case 1, radiotherapy was performed, and in Case 2, resection, intraoperative radiotherapy, and postoperative radiotherapy were performed. Subsequently, both cases received carboplatin and piroxicam treatment. No sign of recurrence has been seen for two years in Case 1 and one year in Case 2. Because tooth extraction can facilitate the spread of gingival lesions to the nasal cavity, it is important to perform a histological analysis prior to tooth extraction.
\end{abstract}

Key word : canine oral squamous cell carcinoma, radiation therapy, tooth extraction

Periodontal disease is one of the most common diseases occurring in domesticated dogs and cats [5], thus, in the United States, most small animals older than 6 years have periodontal disease [13]. The common cause of periodontal disease is gingival plaque [13], and plaque induces gingivitis and periodontitis in periodontal tissue [5]. Plaque-induced chronic inflammation of the gingiva can cause gingival hyperplasia [13]. In such cases, periodontal therapy is generally performed, and gingivectomy is performed as necessary [13].

Head and neck tumors are the third most common tumors after skin and breast tumors, and oral tumors account for the majority of head and neck tumors [10]. The incidence of malignancy, including melanoma, squamous cell carcinoma, and fibrosarcoma, is 59.6\% [10]. Squamous cell carcinoma arises in the normal gingiva of older dogs, and it needs to be resected with a sufficient margin [9].

With gingival lesions in older animals, treatments for periodontal diseases and tumors, including squamous cell carcinoma, differ, and it is important to differentiate between them. The cases of two dogs in which squamous cell carcinoma arose in the gingiva and invaded the nasal cavity soon after tooth extraction are presented.

Case 1 : An 8-year-old, male Pomeranian, weighing $4.9 \mathrm{~kg}$, developed swelling in the canine gingiva and was brought to another veterinary hospital. The tumor was resected, and the mobile canine tooth was extracted. On pathology, squamous cell carcinoma (margin unknown) was confirmed. Because the tumor recurred soon after surgery, the dog was brought to the Azabu University Veterinary Teaching Hospital. At the initial visit, a 2-cm tumor was seen in the left upper canine gingiva (Figure 1). Nasal bleeding was also observed. Physical examination and blood work showed no abnormalities. Chest X-rays showed no lung metastases. A computer tomography (CT) scan revealed bone destruction in the maxilla above the canine tooth, with tumor invading into the nasal cavity (Figure 2). The TNM classification at this time was T2bN0M0, stage II. Radiotherapy was performed (32 Gy, 4 fractions, 21 days), and carboplatin ( $80-100 \mathrm{mg} / \mathrm{m}^{2}$, every three weeks,

1) Veterinary Teaching Hospital, Azabu University, 1-17-71 Fuchinobe, Chuo, Sagamihara, Kanagawa, 252-5201 Japan

2) School of Veterinary Medicine, Azabu University, 1-17-71 Fuchinobe, Chuo, Sagamihara, Kanagawa, 252-5201 Japan

3) Japan Small Animal Medical Center, 2-27-4 Natomi-minmi, Tokorizawa-shi, Saitama 359-0003 Japan

Corresponding author : Takuo Shida Telephone: 042-769-2363 Facsimile : 042-769-2418 E-mail address : shida@azabu-u.ac.jp

Received : September 1, 2010 / October 18, 2010 


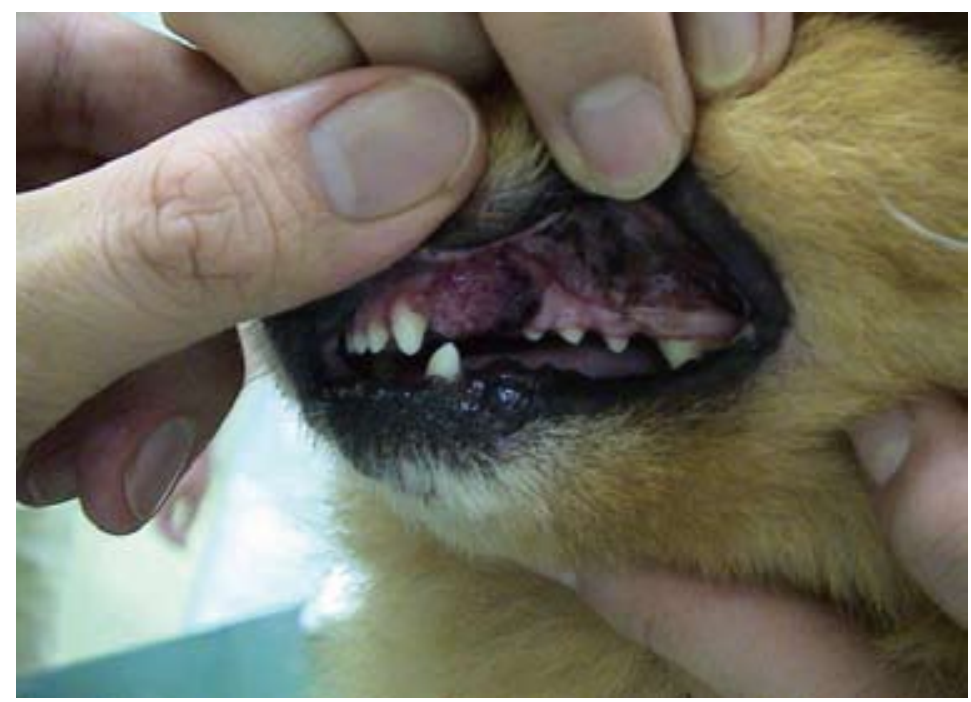

Fig. 1. Gingival mass in Case 1

The canine tooth was extracted, and a tumor is seen in the same location.

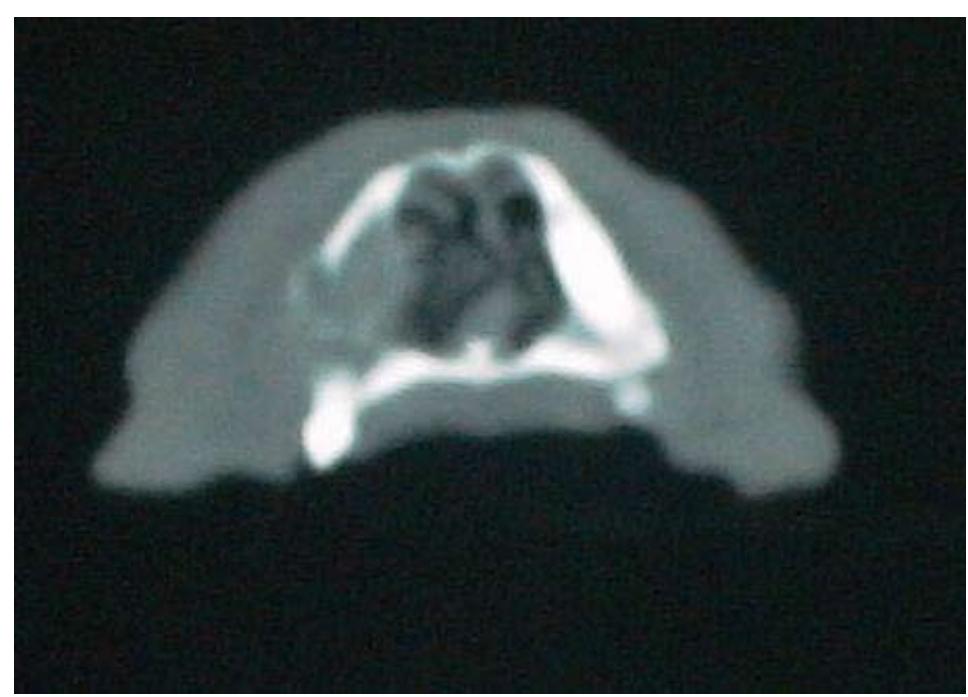

Fig. 2. CT scan of Case 1

The canine tooth was extracted, but the root is not seen. A soft tissue lesion is seen in the nasal cavity.

total dose $\left.1260 \mathrm{mg} / \mathrm{m}^{2}\right)$ and piroxicam $(0.3 \mathrm{mg} / \mathrm{kg}$, QOD) were administered after radiation therapy. One month after the completion of radiotherapy, the tumor disappeared, and epistaxis also stopped. Adverse effects from radiotherapy, such as local epilation and pigmentation, were noted. At this stage, CT showed no lesion in the nasal cavity, and bone regeneration was seen in the defect. At present, the dog' s hair has grown back, and no sign of recurrence has been seen for 30 months.

Case 2: A 13-year-old female west highland white terrier developed redness in the lateral gingiva of the left upper first premolar three months earlier. The dog was put on clindamycin and piroxicam for gingivitis treatment. The dog temporarily responded to medication, though relapses were seen due to persistent gingivitis. The previous veterinarian performed tooth extraction and gingivitis removal one week before the initial visit. On histopathology, squamous cell carcinoma (dirty margin) was confirmed, and, because of rapid lesion recurrence and growth, the dog was brought to Azabu University Veterinary Teaching Hospital. The second and third premolars had been extracted, and in the same area, gingival redness and an ulcer were confirmed (Figure 3). The ipsilateral mandibular lymph node was $1 \mathrm{~cm}$ in size and was not fixed, but diagnostic cytology confirmed invasion of epithelial tumor cells and normal lymphocytes. On day 7 of the illness, CT confirmed nasal cavity invasion (Figure 4). The preoperative TNM classification was T2bN1bM0, and the preopera- 


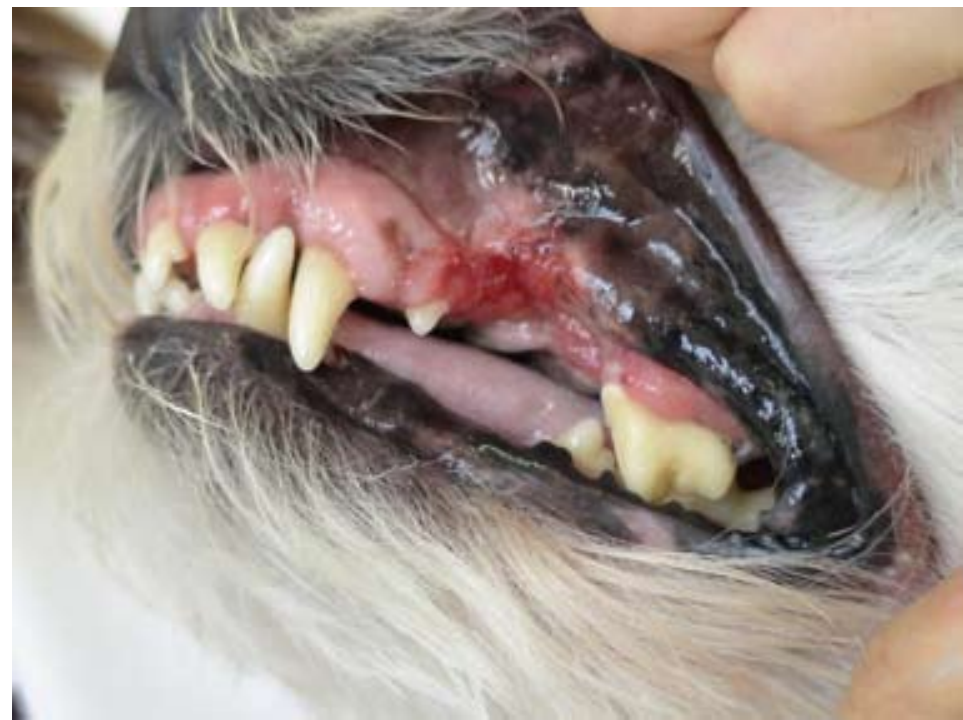

Fig. 3. Gingival lesion in Case 2

The second and third premolars were extracted, and an ulcerated lesion is seen in the same location.

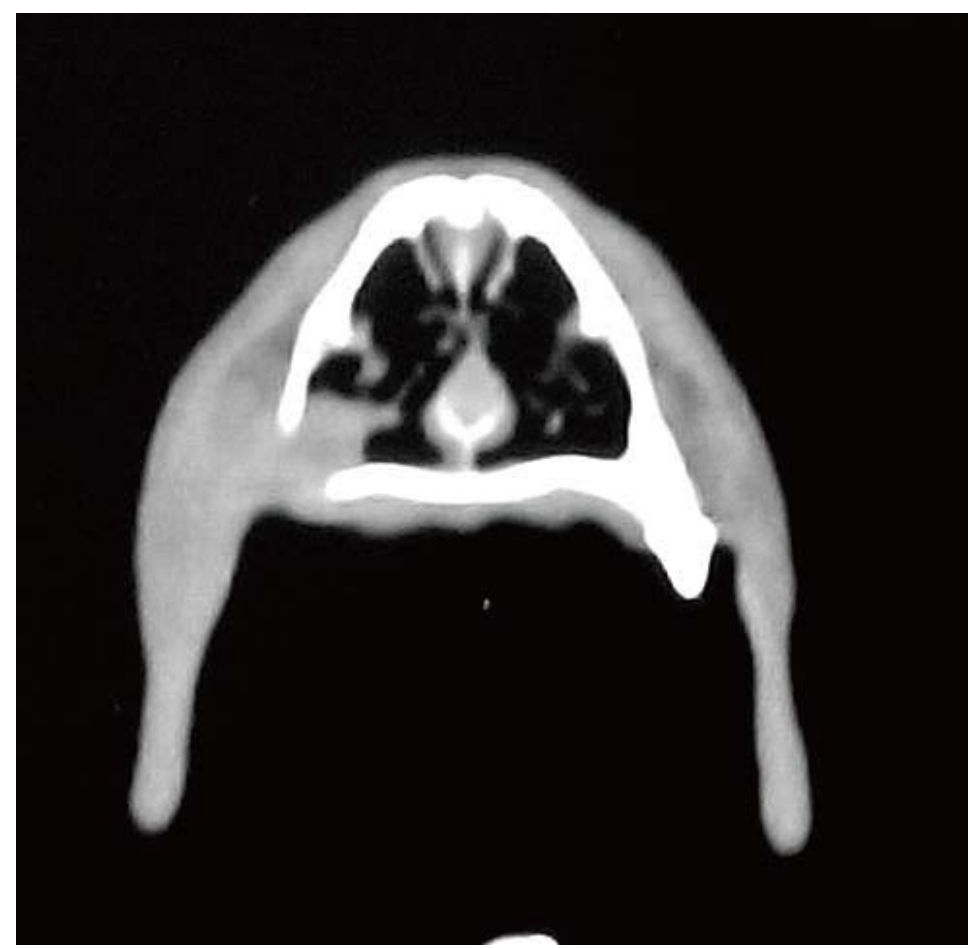

Fig. 4. CT scan of Case 2

After tooth extraction, the tumor can be seen to invade the nasal cavity.

tive stage was III. The lesion was removed and intraoperative radiotherapy (3 MeV, 10 Gy) and ipsilateral mandibular lymph node dissection were performed. At the same time, a lesion that was seen on CT in the contralateral mandibular postmolar was biopsied and analyzed histologically. This lesion was also diagnosed as squamous cell carcinoma, and, starting on day 21 of the illness, external radiotherapy was performed (maxilla : 20 Gy, 4 fractions, and mandible : 28 Gy, 4 times). One month after the end of radiotherapy, the tumor disappeared macroscopically, and CT confirmed improvements in the osseous lesions. Carboplatin (100-110 mg/m², every three weeks, 6 times) and piroxicam ( $0.3 \mathrm{mg} / \mathrm{kg}, 3 \mathrm{days}, 1 \mathrm{time})$ were then administered. At present, no sign of recurrence has been seen for 12 months, and the dog is doing well. 
Squamous cell carcinoma is highly locally invasive $[6,8,9]$. It causes tooth mobility by destroying the periodontal tissue [6], and a tumor arising in the maxilla may invade the nasal cavity [6]. Tooth mobility was seen in case 1 suggesting the existence of an osseous lesion from the beginning. Although the tooth was extracted, symptoms such as nose bleeding and sneezing were detected. On the other hand, in case 2, no tooth mobility nor nasal symptoms were detected before the tooth extraction. In these two cases, we conclude that tumor invasion to the nasal cavity likely was caused by the tooth extraction done at the first veterinary hospitals.

In Case 1, radiotherapy has achieved long-term control. If we had been treating this case by surgery alone, the range of resection would have been extensive, the degree of change in outward appearance would have been great, and the probability of recurrence would have been high. In Case 2, if the surgical margin for the initial surgery had been sufficient, postoperative radiotherapy would not have been required, but because tooth extraction facilitated the spread of the tumor, more extensive therapy was required. The rate of distal metastasis is low for squamous cell carcinoma arising in canine gingiva, and the prognosis is generally favorable for tumors arising in the rostral area [8, 9]. However, squamous cell carcinoma often invades bone, and partial maxillectomy or mandibulectomy is required [7]. In the present two cases, the tumor arose in the canine or premolar area, so the cancer could have been cured if the surgical margin for the initial surgery had been properly established.

Compared to oral melanoma and fibrosarcoma, the duration of local control by radiotherapy is longer in oral squamous cell carcinoma [12]. Théon and colleagues [12] reported that dogs with oral squamous cell carcinoma at a classification of T2 had a local control period of 27.6 months. They stated that smaller lesions had better local control periods. They administered 12 fractions of radiation therapy over a 4-week period with a total of $48 \mathrm{~Gy}$. In the present study, both cases had small lesions, classified at T2. They both underwent hypofractionated radiation therapy protocols. The local control was favorable, and so far, no sign of recurrence has been seen.

Case 1 and the mandibular lesion of case 2 received only radiation therapy, so some residual cancer cells could have remained at the local site. Both cases underwent chemotherapy (carboplatin) and piroxicam combination therapy after irradiation. With respect to drug therapy for oral squamous cell carcinoma, studies have reported the efficacy of piroxicam therapy alone [11], piroxicam and cisplatin combination therapy [1], and piroxicam and carboplatin combination therapy [3]. Due to strong nephrotoxicity and gastrotoxicity, cisplatin and piroxicam are not recommended [4], and full doses of carboplatin and piroxicam can also cause gastrotoxicity [2]. In the present cases, the doses of these agents were reduced so their efficacy can not be properly established, though adverse events were not seen.

Gingival lesions can be malignant at times, and tooth extraction can lead malignant tumor lesion to disseminate. It is preferable to conduct histopathological analysis prior to tooth extraction when gingival abnormality is present.

\section{References}

[1] Boria, P. A., Murry, D. J., Bennett, P. F., Glickman, N. W., Snyder, P. W., Merkel, B. L., Schlittler, D. L., Mutsaers, A. J., Thomas, R. M. and Knapp, D. W. (2004) : Evaluation of cisplatin combined with piroxicam for the treatment of oral malignant melanoma and oral squamous cell carcinoma in dogs. J. Am. Vet. Med. Assoc. $224: 388-394$.

[2 $]$ Boria, P. A., Glickman, N. W., Schmidt, B. R., Windmer, W. R., Mutsaers, A. J., Adams, L. G., Snyder, P. W., DiBernardi, L., de Gortari, A. E., Bonney, P. L. and Knap, D. W. (2005) : Carboplatin and piroxicam therapy in 31 dogs with transitional cell carcinoma of the urinary bladder. Vet. Comp. Oncol. $3: 73-80$.

[ 3 ] de Vos, J. P., Burm, A. G. D., Focker, A. P., Boschloo, H., Karsijns, M. and van der Waal, I. (2005) : Piroxicam and carboplatin as a combination treatment of canine oral non-tonsillar squamous cell carcinoma : a pilot study and a literature review of a canine model of human head and neck squamous cell carcinoma. Vet. Comp. Oncol. $3: 16-24$.

[ 4 ] Greene, S. N., Lucroy, M. D., Greenberg, C. B., Bonny, P. L. and Knapp, D. W. (2007) : Evaluation of cisplatin administered with piroxicam in dogs with transitional cell carcinoma of the urinary bladder. J. Am. Vet. Med. Assoc. 231 : 1056-1060.

[5] Harvey, C. E. (2005) : Management of periodontal disease : understanding the options. In : Veterinary Clinics of North America : Small Animal Practice, Dentistry, (Holmstrom, S. E. ed.), pp. 819-836. Saunders, Philadelphia.

[6] Head, K. W., Else, R. W. and Dubielzig, R. R. (2002) : Tumors of the alimentary tract. In : Tumors in Domestic Animals 4th ed. (Meuten, D. J. ed.), pp. 401-481. Blackwell Publishing Company, Ames.

[ 7 ] Hedlund, C. S. and Fossum, T. W. (2006) : Surgery of the digestive system. In : Small Animal Surgery 3rd ed. (Fossum T. W. ed.), pp. 339-530.Mosby, St. Louis. 
[8] Liptak, J. M. and Withrow, S. J. (2007) : Cancer of the gastrointestinal tract. In : Small Animal Clinical Oncology 4th ed. (Withrow, S. J. and Vail, D. M. eds.), pp. 455-510. Saunders, St. Louis.

[9] Moore, A. S. and Ogilvie, G. K. (2006) : Tumors of the gastrointestinal tract. In:Managing the Canine Cancer Patient (Ogilvie, G. K. and Moore, A. S. eds.), pp. 425-456. Veterinary Learning Systems, Yardley.

[10] Shida, T., Maruo, T., Kawamura, H., Takeda, H., Madarame, H., Kayanuma, H. and Suganuma, T. (2008) : An epidemiological study on tumors in 5,819 dogs. J. Jpn. Vet. Med. Assoc. 61:867-872 (in Japanese).

[11] Schmidt, B. R., Glickman, N. W., DeNicola, D. B., de Gortari, A. E. and Knapp, D. W. (2001) : Evaluation of piroxicam for the treatment of oral squamous cell carcinoma in dogs. J. Am. Vet. Med. Assoc. $218: 1783-1786$.

[12] Théon, A. P., Rodriguez, C. and Madewell, B. R. (1997) : Analysis of prognostic factors and patterns of failure in dogs with malignant oral tumors treated with megavoltage irradiation. J. Am. Vet. Med. Assoc. $210: 778-784$.

[13] Tholen, M. and Hoyt Jr, R. F. (1990) : Oral pathology. In:Small Animal Oral Medicine and Surgery (Bojrab, M. J. and Tholen, M. eds.), pp. 25-55. Lea \& Febiger, Philadelphia. 


\title{
报歯により病期が進行したと考えられるイヌの口埶扁平上皮癌の2例
}

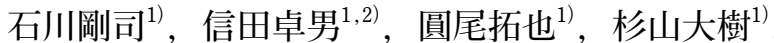 \\ 金久保佳代 ${ }^{3)}$ ，伊藤哲郎 ${ }^{1{ }^{1}}$ ，茅沼秀樹 ${ }^{1,2)}$ ，菅沼常徳 ${ }^{1,2)}$
}

\section{和文要約}

歯肉に発生した腫瘤に対し、腫瘤切除と抜歯を行われていた2例に遭遇した。扁平上皮癌と診断され、早期に再発したた め麻布大学附属動物病院に紹介された。CTにより両例とも鼻埶内への浸潤が認められた。症例1は放射線治療を、症例2 は切除と術中照射打よび術後照射を実施した。その後にカルボプラチンとピロキシカムを投与し、症例1は2年、症例 2 は 1 年経過しているが再発を示唆する症状は認められなかった。抜菌を行うことで鼻腔内への浸潤が容易となるため、抜荿を 行う前に組織学的検査をすることが重要である。

Key word : canine oral squamous cell carcinoma, radiation therapy, tooth extraction

1）麻布大学附属動物病院 =252-5201 神奈川県相模原市中央区淵野辺1-17-71

2）麻布大学獣医学部 =252-5201 神奈川県相模原市中央区淵野辺1-17-71

3）日本小動物医療センター = 359-0003 埼玉県所沢市中富南2-27-4

連絡責任者：信田卓男 麻布大学附属動物病院 ₹252-5201 神奈川県相模原市中央区淵野辺1-17-71 電話042-769-2363、

FAX042-769-2418 メールアドレス：shida@azabu-u.ac.jp

受付日：2010年9月1日、採択日：2010年10月18日

(c)2010. Japan Veterinary Cancer Society 